\title{
ADF1 and BEAF-32 chromatin proteins affect nucleosome positioning and DNA decompaction in 61C7/C8 interband region of Drosophila melanogaster polytene chromosomes
}

\author{
M.B. Schwartz (Berkaeva), T.E. Pankova, S.A. Demakov $\otimes$ \\ Institute of Molecular and Cellular Biology, SB RAS, Novosibirsk, Russia \\ (बe-mail: demakov@mcb.nsc.ru
}

\begin{abstract}
The formation of interphase chromosomes is a multi-level process in which DNA is compacted several thousandfold by association with histones and non-histone proteins. The first step of compaction includes the formation of nucleosomes - the basic repeating units of chromatin. Further packaging occurs due to DNA binding to histone $\mathrm{H} 1$ and non-histone proteins involved in enhancer-promoter and insulator interactions. Under these conditions, the genome retains its functionality due to the dynamic and uneven DNA compaction along the chromatin fiber. Since the DNA compaction level affects the transcription activity of a certain genomic region, it is important to understand the interplay between the factors acting at different levels of the packaging process. Drosophila polytene chromosomes are an excellent model system for studying the molecular mechanisms that determine DNA compaction degree. The unevenness of DNA packaging along the chromatin fiber is easily observed along these chromosomes due to their large size and specific banding pattern. The purpose of this study was to figure out the role of two non-histone regulatory proteins, ADF1 and BEAF-32, in the DNA packaging process from nucleosome positioning to the establishment of the final chromosome structure. We studied the impact of mutations that affect ADF1 and BEAF-32 binding sites on the formation of $61 \mathrm{C} 7 / \mathrm{C} 8$ interband - one of the decompacted regions of Drosophila polytene chromosomes. We show that such mutations led to the collapse of an interband, which was accompanied with increased nucleosome stability. We also find that ADF1 and BEAF-32 binding sites are essential for the rescue of lethality caused by the null allele of bantam microRNA gene located in the region $61 \mathrm{C} 7 / \mathrm{C} 8$. Key words: Drosophila; nucleosome; polytene chromosome; interband; transcription.
\end{abstract}

For citation: Schwartz (Berkaeva) M.B., Pankova T.E., Demakov S.A. ADF1 and BEAF-32 chromatin proteins affect nucleosome positioning and DNA decompaction in 61C7/C8 interband region of Drosophila melanogaster polytene chromosomes. Vavilovskii Zhurnal Genetiki i Selektsii =Vavilov Journal of Genetics and Breeding. 2019;23(2):154-159. DOI 10.18699/VJ19.475

\section{Хроматиновые белки ADF1 и BEAF-32 \\ влияют на позиционирование нуклеосом \\ и упаковку ДНК междиска 61С7/C8 политенных хромосом Drosophila melanogaster}

\author{
М.Б. Шварц (Беркаева), Т.Е. Панкова, С.А. Аемаков
}

Институт молекулярной и клеточной биологии Сибирского отделения Российской академии наук, Новосибирск, Россия 目e-mail:demakov@mcb.nsc.ru

\begin{abstract}
Формирование интерфазной хромосомы представляет собой многоуровневый процесс, в результате которого ДНК упаковывается в тысячи раз. На первом этапе упаковки образуются нуклеосомы - базовые повторяющиеся единицы хроматина. Дальнейшая упаковка происходит за счет связывания ДНК с гистоном Н1 и негистоновыми белками, участвующими в ближних и дальних энхансер-промоторных и инсуляторных взаимодействиях. При этом функциональность генома сохраняется за счет динамичной и неравномерной упаковки ДНК вдоль хромосомы, что проявляется уже на нуклеосомном уровне. Несмотря на долгую историю изучения процесса упаковки ДНК в интерфазном ядре, до сих пор до конца не ясно, от чего зависит степень упаковки разных участков ДНК и какое влияние оказывают друг на друга разные уровни упаковки. Превосходной модельной системой для изучения молекулярных механизмов, определяющих степень упаковки ДНК, являются политенные хромосомы слюнных желез личинок дрозофилы. За счет больших размеров и характерного диск/междискового рисунка они позволяют легко наблюдать неравномерность упаковки ДНК вдоль хромосом. В настоящей работе мы исследовали, какую роль играют негистоновые регуляторные белки ADF1 и BEAF-32 в позиционировании нуклеосом и формировании междиска 61C7/C8 - одного из декомпактных районов политенных хромосом. ADF1 - специфический транскрипционный фактор, а BEAF-32 - инсуляторный белок, ассоциированный с междисками. С использованием трансгенных линий мы показали, что
\end{abstract}




\begin{abstract}
мутации сайтов связывания ADF1 или BEAF-32 приводят к тому, что трансген теряет способность формировать междиск в новом генетическом окружении. Кроме того, мутации нарушают нуклеосомную организацию трансгена, характеризующуюся повышением стабильности нуклеосом. Мы обнаружили, что сайты связывания ADF1 и BEAF-32 необходимы для спасения нуль-аллеля bantam - жизненно важного гена микроРнК, расположенного в районе 61С7/С8. Таким образом, мы можем проследить связь между степенью упаковки ДНК, нуклеосомной организацией и функцией конкретного участка интерфазной хромосомы.

Ключевые слова: дрозофила; нуклеосома; политенная хромосома; междиск; транскрипция.
\end{abstract}

\section{Introduction}

Eukaryotic DNA is organized in a compact nucleoprotein complex called chromatin. Nucleosomes is the basic unit of chromatin and consists of 147 bp of DNA wrapped around a histone octamere. Nucleosome arrays form a so-called " $10-\mathrm{nm}$ fibril" which is further folded into higher order chromatin structures by histone $\mathrm{H} 1$ and a large number of functionally different non-histone proteins. The resulting structure constitutes an eukaryotic chromosome. Despite the long history of chromosome formation, mutual influence between the different DNA compaction levels is still unclear. On the one hand, nucleosome positioning determines the availability of DNA for the binding of non-histone proteins that regulate transcription and replication. On the other hand, non-histone proteins affect nucleosome positioning: they can destroy a nucleosome by displacing histone octamer or recruit ATP-dependent remodeling complexes that move the nucleosomes along the chromosomes. Moreover, nucleosome arrays are thought to self-organize against the potential barrier introduced by DNA-bound non-histone protein complexes due to the steric exclusions between adjacent nucleosome particles (Chereji et al., 2016; Chereji, Clark, 2018).

Drosophila polytene chromosomes provide a convenient model of interphase chromatin and allow to study the interplay between DNA compaction, chromatin structure, and transcription activity. Polytene chromosomes are formed in salivary glands of third instar larvae in the process of endoreplication and display a characteristic repetitive pattern of densely compacted bands interleaving with decompacted regions, called interbands. The compaction level of a given DNA region is determined by its function and the corresponding chromatin state. Interbands are formed by open chromatin and usually contain gene promoters, enhancers and insulators. Furthermore, interbands coincide with the nucleosome-free regions or contain weakly positioned nucleosomes (Zhimulev et al., 2014). These features make interbands a unique tool for studying the role of non-histone regulatory proteins in nucleosome positioning and the formation of chromomeric pattern of interphase chromosomes.

Here, we study the role of two regulatory non-histone proteins - ADF1 and BEAF-32 - in the nucleosome positioning and interband formation in the region $61 \mathrm{C} 7 / \mathrm{C} 8$ of polytene chromosomes. This region was chosen because the DNA sequence sufficient to establish and maintain the decompacted state of the $61 \mathrm{C} 7 / \mathrm{C} 8$ interband was determined earlier (Semeshin et al., 2008). Interband 61C7/C8 encompasses a bantam miRNA gene and regulatory elements controlling its expression, including ADF1 and BEAF-32 binding sites (Brennecke et al., 2003). ADF1 is a transcription factor and BEAF-32 is an insulator protein that is also associated with the transcription activation. Both of the proteins are involved in the establishment and maintenance of local chromatin state
(Jiang et al., 2009; Orsi et al., 2014). Previously, we showed that ADF1 and BEAF-32 localized to the $61 \mathrm{C} 7 / \mathrm{C} 8$ interband in salivary gland polytene chromosomes (Berkaeva et al., 2009). BEAF-32 is known as an interband-specific protein (Zhimulev et al., 2014) and its binding to DNA is crucial for the polytene chromosome structure (Gilbert et al., 2006). Mapping of nucleosomes in Drosophila cell cultures suggests that binding of BEAF-32 to DNA causes the formation of potential barriers that determine the positioning of neighboring nucleosomes (Chereji et al., 2016).

We found that ADF1 and BEAF-32 binding sites were indispensable for $61 \mathrm{C} 7 / \mathrm{C} 8$ interband formation. Although the mutations of both binding sites caused the interband disappearance, the associated changes in nucleosomal organization were distinct. Therefore, different molecular mechanisms underlying those changes were proposed. Additionally, we report here that ADF1 and BEAF-32 play an essential role in the regulation of bantam expression.

\section{Materials and methods}

Fly stocks. To obtain transgenic flies, we used a stock with an attP-site located in the 10A1-2 region of the X chromosome (Andreenkov et al., 2016). Transgenic stock " 4.7 " carried an insertion of the original unmutated " 4.7 " fragment, stock "ADF" contained the insertion of the "4.7" fragment with mutated ADF-1 binding site, and "BEAF" contained the insertion of the " 4.7 " fragment with mutated BEAF-32 binding site.

All transgenic flies had $y^{1}$ and $D f(1) w^{67 c 23}$ mutations in the $\mathrm{X}$ chromosome and a lethal deletion $\operatorname{ban}^{\Delta 1}$ maintained against TM6B balancer.

Control "yw" flies had wild-type chromosomes except for the $\mathrm{X}$ which carried $y^{1}$ and $D f(1) w^{67 c 23}$ mutations.

Mutations in protein binding sites. The DNA fragment sufficient to form the $61 \mathrm{C} 7 / \mathrm{C} 8$ interband was $4709 \mathrm{bp}$ in length (3L: 637635-642343, release $=$ r6.23) and was named as the "4.7" fragment. It encompassed ADF1 and BEAF-32 binding sites, bantam miRNA hairpin and two putative promoters of the bantam gene (Fig. 1)

ADF1 binding site in the " 4.7 " fragment consisted of three motifs which corresponded to the consensus (England et al., 1992). Two overlapping motifs were removed by SalI-SphI excision and the third one was disrupted by replacing $7 \mathrm{nu}-$ cleotides with a stretch of As. Shown below is a portion of the "4.7" fragment that includes the ADF1 binding site:

...ATGcgacttcaaacatagttcggcatcgaaactttctagcacaccga cacacatacgaacgcgatccagcegacacacacacacacacgcacgcagc cacacacttaagcgactttcgaaaggtacaactttttacgaagtcgctgect cggcegctgtgcagcegacgecactgccgetgccgetgtcgetgcetctg TCGACTTCGAATTCCAACGCCAAGATGAAAGATC GGCGCAAAAGAAAAGAAATATTCATTCAGTA AAATTTGATAGCTGCAAAAAAAAGCCGCATGG... 


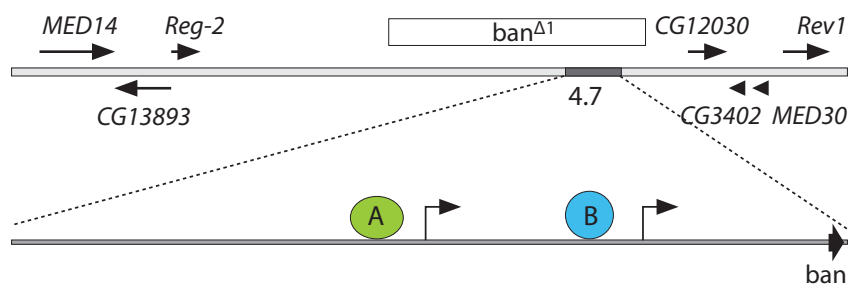

Fig. 1. Molecular and genetic organization of the $61 C 7 / C 8$ region of 3L-chromosome.

Position of the "4.7" fragment on the genetic map is marked with a dark gray rectangle. Ovals " $\mathrm{A}$ " and " $\mathrm{B}$ " indicate ADF1 and BEAF-32 binding sites, respectively. Curved arrows denote putative promoters of the bantam gene (Brennecke et al., 2003; Qian et al., 2011). A thick black arrow indicates the position of bantam miRNA hairpin. White rectangle in the upper part of the figure indicates ban $^{\Delta 1}$ deletion.

The first nucleotide of the sequence above is 3L: 639461 (Drosophila genome release r6.23). The nucleotides included in the consensus motifs are underlined, deleted nucleotides are shown in lowercase, and inserted nucleotides are shown in bold.

BEAF-32 binding sites are characterized by the presence of CGATA motifs that are positioned in a certain way (Jiang et al., 2009). Two CGATA motifs on the forward and reverse DNA strands were deleted by ClaI excision:

\section{GAATATCGATatgatatcgatGGGA}

The first nucleotide of the sequence above is 3L: 641006 (release r6.23). Only forward DNA strand is presented. Forward and reverse CGATA motifs are underlined and deleted nucleotides are shown in lowercase.

Original "4.7" fragment and the mutated variants were cloned into pUni-mod vector (Andreenkov et al., 2016) using $K p n I$ and Not I restriction sites. The constructs obtained were used to create transgenic flies.

Cytology. Squashed preparations of the salivary gland polytene chromosomes were made by the standard technique and analyzed by phase-contrast microscopy, as described earlier (Zhimulev et al., 1982).

Nucleosome profiling. To study the nucleosome positioning, 100 pairs of salivary glands of third-instar larvae were extracted in PBS and then treated with 700 units of MNase (BioLabs; M0247S) at $+25^{\circ} \mathrm{C}$ for $3 \mathrm{~min}$. Under those conditions, mono-, di- and tri-nucleosomes were obtained. Thus, the nucleosomes with different sensitivity to MNase hydrolysis (Chereji et al., 2016) were in our nucleosomal profile. Nucleosomal DNA was isolated by phenol extraction. Mononucleosomal DNA was eluted from $1.5 \%$ agarose gel using a DNA gel extraction kit (BioSilica) and analyzed by Real-Time PCR with a set of primers spanning the entire " 4.7 " fragment. The concentration of DNA was determined using the method of calibration curves. To establish calibration curves, genomic DNA was isolated from the brain ganglia of the same larvae that were used for salivary gland isolation. The copy number of DNA along the entire chromosome is the same in diploid brain ganglia, while in salivary glands different parts of the same chromosome can be polytenized to a different extent. An amplicon from the $h s p 26$ locus corresponding to a precisely positioned nucleosome (Thomas, Elgin, 1988) was used as an internal control to take into account the pipetting errors.
Nucleosome stability was assessed as the ratio of nucleosomal DNA to the genomic DNA isolated from salivary glands not treated with MNase.

Real-Time PCR data were quantified as follows. The concentrations of mononucleosomal $\left(\mathrm{M}_{\text {Amplicon }}\right)$ and untreated DNA $\left(\mathrm{U}_{\text {Amplicon }}\right)$ for each amplicon were normalized by the concentrations of the hsp 26 amplicon in mononucleosomal $\left(\mathrm{M}_{h s p 26}\right)$ and untreated DNA $\left(\mathrm{U}_{h s p 26}\right)$, respectively:

$$
\frac{\mathrm{M}_{\text {Amplicon1 }}}{\mathrm{M}_{h s p 26}}=\mathrm{M}_{\frac{\mathrm{A} 1}{h s p 26}} ; \frac{\mathrm{U}_{\text {Amplicon1 }}}{\mathrm{U}_{h s p 26}}=\mathrm{U}_{\frac{\mathrm{A} 1}{h s p 26}} .
$$

The normalized concentration data for mono-nucleosomes were divided by the normalized concentration for untreated DNA to determine the representation of the amplicon in mononucleosome fraction:

$$
\frac{\mathrm{M}_{\frac{\mathrm{A} 1}{h s p 26}}}{\mathrm{U}_{\frac{\mathrm{A} 1}{h s p 26}}}=\mathrm{M}_{1} .
$$

Some of the amplicons demonstrated nearly zero representation (for example, see Fig. 3, amplicons \# 8, 9). This indicated that the underlying sequence was not fully protected from MNase hydrolysis. However, it cannot be excluded that the nucleosome is only slightly shifted relative to the amplicon, therefore one of the primers does not fit into the nucleosomal DNA.

All experiments were performed as two biological repeats, each consisted of three technical replicas. The representation data obtained in different transgenic flies were compared separately for each amplicon. The significance of differences was assessed using Student's criterion. The nucleosomal profiles of transgenes were studied in ban $^{\Delta 1}$ deletion background to eliminate the possible contribution of the native $61 \mathrm{C} 7 / \mathrm{C} 8$ interband in the $3 \mathrm{~L}$ chromosome (Brennecke et al., 2003).

\section{Results and discussion}

ADF1 and BEAF-32 binding sites are important for interband formation. The $4.7 \mathrm{~kb}$ DNA fragment from the $61 \mathrm{C} 7 / \mathrm{C} 8$ region (hereinafter referred to as the " 4.7 " fragment) is able to form the interband when relocated into a new genomic position (Semeshin et al., 2008). This means that all the factors determining the interband formation are within this piece of DNA. We propose that the initial step of the interband formation involves DNA binding by some regulatory proteins which further recruit chromatin remodeling complexes capable of establishing and maintening the "open" chromatin structure. Putative binding sites for several proteins were identified within the "4.7" sequence, but only ADF1 and BEAF-32 were precisely mapped to the $61 \mathrm{C} 7 / \mathrm{C} 8$ interband in salivary glands (Berkaeva et al., 2009). Therefore we asked whether these proteins may have a role in interband formation. We used transgenic assays to answer this question. The original " 4.7 " fragment and its modifications with disrupted ADF1 and BEAF-32 binding sites were inserted in the10A1-2 region which forms a thick band in the $\mathrm{X}$ polytene chromosome (Fig. 2, upper panel). All the transgenes were inserted exactly in the same position using phiC31-mediated attP-attB recombination system. In doing so, we were able distinguish the effects of mutations from the influence of genomic environment. 
Cytological analysis of polytene chromosome squashed preparations showed that insertion of the original " 4.7 " fragment caused the formation of an ectopic interband that split the 10A1-2 band (see Fig. 2). It is worth noting that the insertion of the transgene was located on the very edge of the thick 10A1-2 band. Thus, the observed splitting of a thin gray band from the distal part of the original 10A1-2 band indicated that the ectopic interband was formed by the transgene material. It should be noted that no 10A1-2 band splitting was observed in the polytene chromosomes of original flies with the attP site in 10A1-2 region (see Fig. 2). Similarly, the mutated variants of the " 4.7 " fragment with disrupted ADF1 or BEAF-32 binding sites were unable to split the 10A1-2 band (see Fig. 2).

The absence of ectopic interband in 10A1-2 region of the polytene chromosomes of "ADF" and "BEAF" flies could be caused by a disturbance of the nucleosome positioning in the transgenes. It was shown previously that binding of ADF1 to the target promoters contributes to the subsequent binding of the transcription factor GAGA (GAF) (Talamillo et al., 2004; Orsi et al., 2014), which recruits NURF remodeling complex (Tsukiyama et al., 1994). It was also shown that depletion of NURF subunits leads to a large-scale redistribution of nucleosomes and disruption of the chromosome organization in Drosophila S2 cells (Moshkin et al., 2012). It was shown that BEAF-32 physically interacts with the insulator protein CP190 (Vogelmann et al., 2014), which functionally interacts with NURF301, a subunit of the NURF complex (Kwon et al., 2016). It should be noted that GAF, CP190, NURF, and BEAF-32 have been shown to bind the native $61 \mathrm{C} 7 / \mathrm{C} 8$ region in Drosophila $\mathrm{S} 2$ cells (www.modencode.org).

Mutations in the ADF1 and BEAF-32 binding sites lead to disturbance of nucleosomal organization. To understand the role of nucleosomal organization in the formation of ectopic interband, we studied nucleosome profiles of all transgenes in larval salivary glands. First of all, we asked whether the transposition of " 4.7 " fragment into the new genomic locus was accompanied with perturbation in nucleosomal organization. We compared nucleosome profile of the " 4.7 " transgene with the profile of native $61 \mathrm{C} 7 / \mathrm{C} 8$ region in the $3 \mathrm{~L}$ chromosome of "yw" larvae. We found that the stability of nucleosomes increased in the "4.7" transgene compared to the native $61 \mathrm{C} 7 / \mathrm{C} 8$ interband (Fig. 3). That was unexpected since the "4.7" transgene formed an interband visually indistinguishable from the native one (see Fig. 2). Genetic environment likely affects the nucleosome positioning in the inserted " 4.7 " fragment, although this impact is not visually manifested at the level of DNA packaging.

Next, we compared the nucleosome profile in the "ADF" transgene with the profile obtained for the " 4.7 " fragment. Deletion in the "ADF" transgene affects the area overlapped by the amplicons 9, 10, 11, so the data for them were unavailable. We found that the stability of nucleosomes between the amplicons 12 and 21 increased while the stability of nucleosomes at the edges of "ADF" transgene decreased in comparison with the "4.7" (see Fig. 3). This is consistent with our idea that NURF binding is disrupted in the "ADF" transgene. It was previously shown that depletion of NURF subunits in the cultured Drosophila cells led to increased nucleosome stability at the center of the areas occupied by the complex and to decreased nucleosome stability at the edges of those areas. The
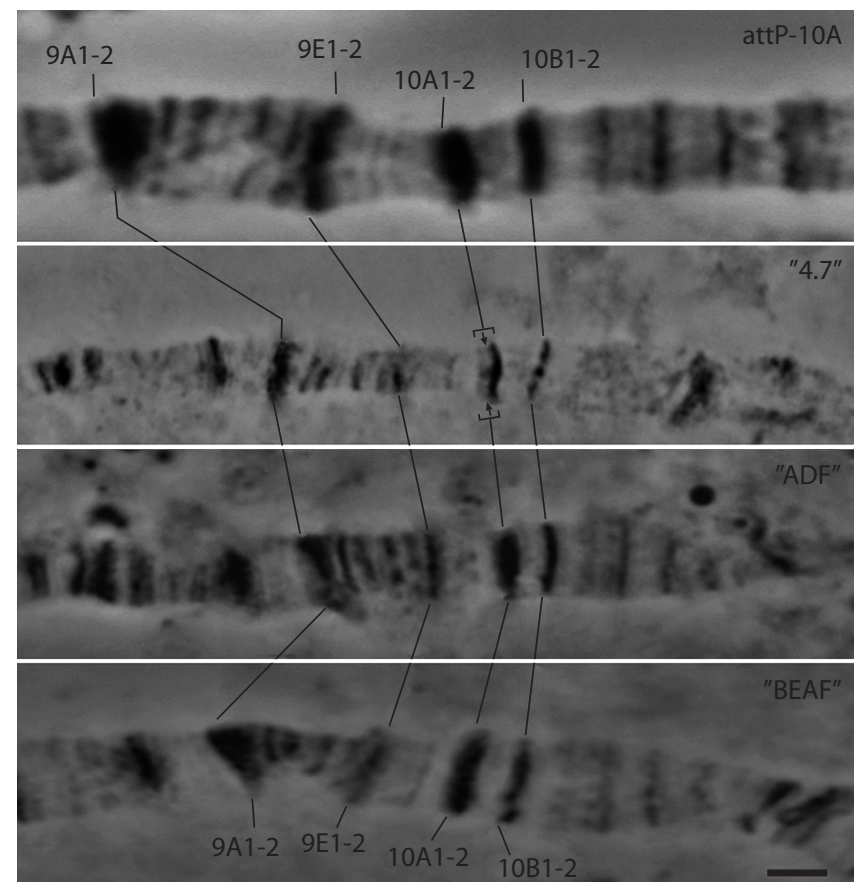

Fig. 2. Morphology of the $X$ chromosome $10 \mathrm{~A} 1-2$ region in transgenic larvae.

Stock names are indicated at the right upper corner of each panel. The top panel shows the chromosome of the original stock with the attP site in 10A1-2 region. Arrows on the "4.7" panel mark the ectopic interband. Scale bar corresponds to $5 \mu \mathrm{m}$.

nucleosomes from the periphery seemed to gather at the place freed from the NURF complex (Moshkin et al., 2012). This is exactly was what we observed for the "ADF" transgene.

Nucleosome stability also increased in the "BEAF" transgene compared with "4.7" (see Fig. 3), however there was no shift of the nucleosomes from the periphery to the center, like in "ADF". Apparently the increase in nucleosome stability in this case was caused by the other factors than altered NURF binding. One of the explanation is based on the fact that BEAF-32 interacts with Chromator protein (Vogelmann et al., 2014) which attracts JIL-1 kinase that phosphorylates the S10 residue of histone H3. Depletion of JIL-1 or Chromator leads to the specific condensation of polytene chromosome interbands (Rath et al., 2006). We proposed that mutation of BEAF-32 binding site in "BEAF" transgene indirectly caused the displacement of JIL-1 and the corresponding decrease in H3S10 phosphorylation which might cause perturbation of nucleosomal organization. It is important to note that nucleosome stability around the mutated BEAF-32 binding site did not decrease. Apparently, at least in this case BEAF-32 does not set a potential barrier that delimits the phasing of surrounding nucleosomes.

ADF1 and BEAF-32 binding sites in bantam regulatory region are important for the viability of flies. The nucleosomal profile of transgenes was studied at $\operatorname{ban}^{\Delta 1}$ background. We noticed that adult flies homozygous for the $\operatorname{ban}^{\Delta 1}$ deletion were only recovered in the "4.7" stock. "ADF" and "BEAF" flies homozygous for the deletion died at the late pupal stage similarly to the flies containing the deletion without any rescue 


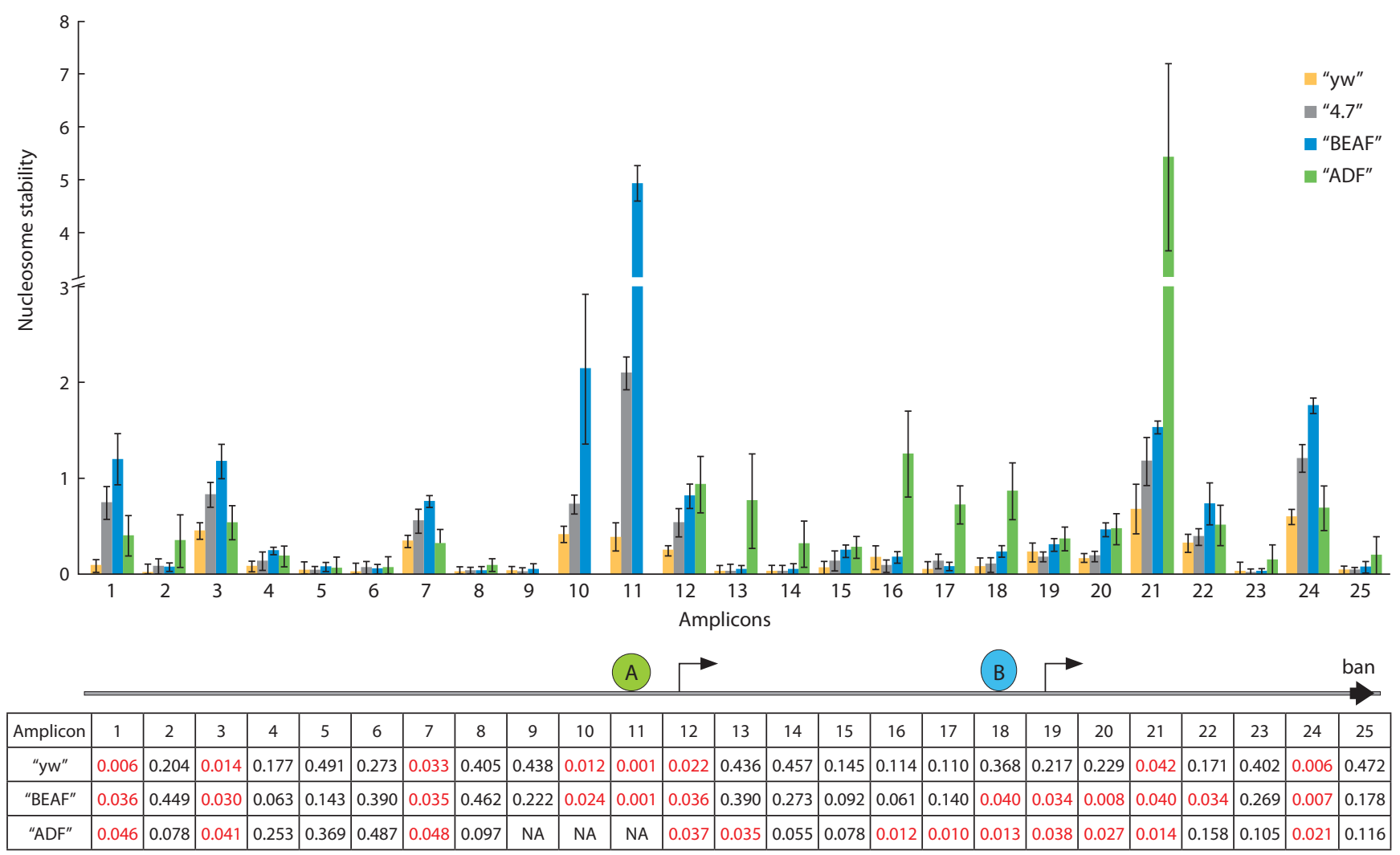

Fig. 3. Comparison of the nucleosome profile of $61 \mathrm{C} 7 / \mathrm{C} 8$ interband in the control " $y w$ " and transgenic flies.

Bars indicate the representation of the corresponding amplicon in the nucleosomal DNA. Yellow bars show the nucleosomal profile of the native $61 \mathrm{C} 7 / \mathrm{C} 8$ interband of "yw" flies; gray bars - in the "4.7" transgene, blue bars - in the "BEAF" transgene, and green bars - in "ADF" transgene. The table below the diagram contains the probability of a random difference in the representation of amplicons in the indicated genotypes compared to the "4.7" stock. Red color highlights the probabilities <0.05; NA - data not available.

transgenes. It was shown that despite the large size of ban ${ }^{\Delta 1}$ deletion $(20 \mathrm{~kb})$, the only essential gene within this deletion is bantam. Expression of bantam hairpin under the ubiquitous driver control was enough to rescue the lethality (Brennecke et al., 2003). The rest of the sequence deleted by ban ${ }^{\Delta 1}$ seems to contain regulatory elements important for spatial and tissuespecific control of bantam expression (Brennecke et al., 2003; Martin et al., 2004; Peng et al., 2009; Oh, Irvine, 2011). The late pupal lethality of "ADF" and "BEAF" flies suggested that mutations of ADF1 and BEAF-2 binding sites led to bantam inactivation in the tissues important for adult fly development.

We would like to dwell in more detail on the mutation of the ADF1-binding site. The thing is that the mutation is not a point replacement but quite a big deletion which could remove more than only ADF-binding site. So we can not exclude the possibility that disruption of some other regulatory elements could cause bantam inactivation. However it is important to mention that our mutation does not destroy the core elements of the neighboring DPE-containing promotor (Berkaeva et al., 2009). Further experiments with point replacement in consensus sequences are needed to assert with the confidence that the ADF1-binding disruption is responsible for the effects we observe in "ADF" transgenic flies.

Interestingly, bantam was shown to be transcriptionally inactive in salivary glands (Kwon et al., 2011) - the tissue where the disappearance of the interband was observed. Previous studies (Zhimulev et al., 2014) suggest that polytene chro- mosome organization reflects the organization of interphase chromosomes in various cell types. So, we hypothesize that bantam inactivation caused by mutations in the ADF1 and BEAF-32 binding sites is accompanied by altered nucleosome positioning and chromatin structure not only in salivary glands but also in diploid tissues that are essential for the fly viability.

\section{Conclusions}

In this study, we investigated the role of non-histone regulatory proteins ADF1 and BEAF-32 in the positioning of nucleosomes and formation of $61 \mathrm{C} 7 / \mathrm{C} 8$ interband - one of the decompacted regions of Drosophila polytene chromosomes. ADF1 is a specific transcription factor and BEAF-32 is an insulator protein associated with interbands. Using transgenic flies, we showed that ADF1 and BEAF-32 binding sites were indispensable for DNA decompaction in $61 \mathrm{C} 7 / \mathrm{C} 8$ interband region. In addition, mutations of $\mathrm{ADF} 1$ and BEAF-32 binding sites disrupted nucleosome positioning in the transgenes, characterized by an increase of nucleosome stability. We also found that ADF1 and BEAF-32 binding sites were required for the rescue of null-allele bantam - an essential miRNA gene located in $61 \mathrm{C} 7 / \mathrm{C} 8$ region. We hope that our findings will be useful for further understanding the mechanisms of interconnection between the degree of DNA packing, nucleosome organization and genomic functions of the particular regions of interphase chromosome. 


\section{References}

Andreenkov O.V., Andreenkova N.G., Volkova E.I., Georgiev P.G., Goncharova A.A., Pokholkova G.V., Demakov S.A. Ectopic tethering of the chromator protein in UASDBD(GAL4) system as approach for studying of the insulator proteins in Drosophila melanogaster polytene chromosomes. Tsitologiia. 2016;58(6):493-497. (in Russian)

Berkaeva M., Demakov S., Schwartz Y.B., Zhimulev I. Functional analysis of Drosophila polytene chromosomes decompacted unit: the interband. Chromosome Res. 2009;17(6):745-754. DOI 10.1007/ s10577-009-9065-7.

Brennecke J., Hipfner D.R., Stark A., Russell R.B., Cohen S.M. Bantam encodes a developmentally regulated microRNA that controls cell proliferation and regulates the proapoptotic gene hid in Drosophila. Cell. 2003;113(1):25-36.

Chereji R.V., Clark D.J. Major determinants of nucleosome positioning. Biophys. J. 2018;114(10):2279-2289. DOI 10.1016/j.bpj.2018. 03.015.

Chereji R.V., Kan T.-W., Grudniewska M.K., Romashchenko A.V., Berezikov E., Zhimulev I.F., Guryev V., Morozov A.V., Moshkin Y.M. Genome-wide profiling of nucleosome sensitivity and chromatin accessibility in Drosophila melanogaster. Nucleic Acids Res. 2016; 44(3):1036-1051. DOI 10.1093/nar/gkv978.

England B.P., Admon A., Tjian R. Cloning of Drosophila transcription factor Adf-1 reveals homology to Myb oncoproteins. Proc. Natl. Acad. Sci. USA. 1992;89(2):683-687.

Gilbert M.K., Tan Y.Y., Hart C.M. The Drosophila boundary elementassociated factors BEAF-32A and BEAF-32B affect chromatin structure. Genetics. 2006;173(3):1365-1375. DOI 10.1534/genetics. 106.056002 .

Jiang N., Emberly E., Cuvier O., Hart C.M. Genome-wide mapping of boundary element-associated factor (BEAF) binding sites in Drosophila melanogaster links BEAF to transcription. Mol. Cell. Biol. 2009;29(13):3556-3568. DOI 10.1128/MCB.01748-08.

Kvon E.Z., Demakov S.A., Zhimulev I.F. Chromatin decompaction in the interbands of Drosophila polytene chromosomes does not correlate with high transcription level. Russ. J. Genet. 2011;47(6):674681. DOI 10.1134/S1022795411060135. (in Russian)

Kwon S.Y., Grisan V., Jang B., Herbert J., Badenhorst P. Genomewide mapping targets of the metazoan chromatin remodeling factor NURF reveals nucleosome remodeling at enhancers, core promoters and gene insulators. PLoS Genet. 2016;12(4):1-26.

Martin F.A., Pérez-Garijo A., Moreno E., Morata G. The brinker gradient controls wing growth in Drosophila. Development. 2004; 131(20):4921-4930. DOI 10.1242/dev.01385.

Moshkin Y.M., Chalkley G.E., Kan T.W., Reddy B.A., Ozgur Z., van Ijcken W.F.J., Dekkers D.H.W., Demmers J.A., Travers A.A., Verrijzer C.P. Remodelers organize cellular chromatin by counteracting intrinsic histone-DNA sequence preferences in a class-specific manner. Mol. Cell. Biol. 2012;32(3):675-688. DOI 10.1128/MCB. 06365-11.

Oh H., Irvine K.D. Cooperative regulation of growth by Yorkie and Mad through bantam. Dev. Cell. 2011;20(1):109-122. DOI 10.1016/j. devcel.2010.12.002.

Orsi G.A., Kasinathan S., Hughes K.T., Saminadin-Peter S., Henikoff S., Ahmad K. High-resolution mapping defines the cooperative architecture of Polycomb response elements. Genome Res. 2014; 24(5):809-820. DOI 10.1101/gr.163642.113.

Peng H.W., Slattery M., Mann R.S. Transcription factor choice in the Hippo signaling pathway: homothorax and yorkie regulation of the microRNA bantam in the progenitor domain of the Drosophila eye imaginal disc. Genes Dev. 2009;23(19):2307-2319. DOI 10.1101/ gad. 1820009 .

Rath U., Ding Y., Deng H., Qi H., Bao X., Zhang W., Girton J., Johansen J., Johansen K.M. The chromodomain protein, Chromator, interacts with JIL-1 kinase and regulates the structure of Drosophila polytene chromosomes. J. Cell Sci. 2006;119(Pt 11):2332-2341.

Semeshin V.F., Demakov S.A., Shloma V.V., Vatolina T.Y., Gorchakov A.A., Zhimulev I.F. Interbands behave as decompacted autonomous units in Drosophila melanogaster polytene chromosomes. Genetica. 2008;132(3):267-279.

Talamillo A., Fernández-Moreno M.A., Martínez-Azorín F., Bornstein B., Ochoa P., Garesse R. Expression of the Drosophila melanogaster ATP synthase $\alpha$ subunit gene is regulated by a transcriptional element containing GAF and Adf-1 binding sites. Eur. J. Biochem. 2004;271(20):4003-4013. DOI 10.1111/j.1432-1033.2004.04336.x.

Thomas G.H., Elgin S.C. Protein/DNA architecture of the DNase I hypersensitive region of the Drosophila hsp26 promoter. EMBO J. 1988;7(7):2191-2201.

Tsukiyama T., Becker P.B., Wu C. ATP-dependent nucleosome disruption at a heat-shock promoter mediated by binding of GAGA transcription factor. Nature. 1994;367(6463):525-532. DOI 10.1038/ $367525 \mathrm{a} 0$.

Vogelmann J., Le Gall A., Dejardin S., Allemand F., Gamot A., Labesse G., Cuvier O., Nègre N., Cohen-Gonsaud M., Margeat E., Nöllmann M. Chromatin insulator factors involved in long-range DNA interactions and their role in the folding of the Drosophila genome. PLoS Genet. 2014;10(8):e1004544. DOI 10.1371/journal. pgen.1004544.

Zhimulev I.F., Semeshin V.F., Kulichkov V.A., Belyaeva E.S. Intercalary heterochromatin in Drosophila. I. Localization and general characteristics. Chromosoma. 1982;87(2):197-228. DOI 10.1007/ BF00338489.

Zhimulev I.F., Zykova T.Y., Goncharov F.P., Khoroshko V.A., Demakova O.V., Semeshin V.F., Pokholkova G.V., Boldyreva L.V., Demidova D.S., Babenko V.N., Demakov S.A., Belyaeva E.S. Genetic organization of interphase chromosome bands and interbands in Drosophila melanogaster. PLoS One. 2014;9(7):e101631. DOI 10.1371/journal.pone.0101631.

Acknowledgements. The work was supported by IMCB SB RAS budget project (No. 0310-2018-0010).

Conflict of interest. The authors declare no conflict of interest.

Received December 10, 2018. Revised December 18, 2018. Accepted January 5, 2019. 